\title{
Investigations of mature Scots pine stands in windthrow areas in Norway spruce forests in Western Rhodopes
}

\author{
Milan Barna $^{1 *}$, Angel Ferezliev² ${ }^{2}$ Hristo Tsakov², Ivan Mihál ${ }^{1}$
}

'Institute of Forest Ecology, Slovak Academy of Sciences, L. Štúra 2, 96053 Zvolen, Slovakia

${ }^{2}$ Forest Research Institute, Bulgarian Academy of Sciences, 132, St. Kliment Ohridski Blvd., Sofia, Bulgaria

\begin{abstract}
Barna, M., Ferezliev, A., Tsakov, H., Mihál, I., 2020. Investigations of mature Scots pine stands in windthrow areas in Norway spruce forests in Western Rhodopes. Folia Oecologica, 47 (1): 1-9.

We investigated the current health condition (defoliation), state of natural regeneration, and mycoflora and phytopathogen-caused attacks in Scots pine forests (Pinus sylvestris L.) planted in the 1960s in areas affected by wind disturbances in the West Rhodope Mountains in Bulgaria. Some damage types (resin outflow and anthropogenic damage) were present to a low extent in the research plots ( $\mathrm{S}$ - Selishte and PK - Pobit Kamak). Some were missing completely (damage by deer and other animals, the presence of lignicolous fungi and abiotic damage). The most important results of this study were the following: i) the occurrence of the bark beetle pest Tomicus minor Hartig (Coleoptera, Scolytinae) was recorded on average in 4.6 (S) and 2.3 (PK) of fallen shoots under the tree crown within $1 \mathrm{~m}$ diameter around the stem; ii) significant damage to tree crowns due to the loss of assimilation organs in Scots pine trees $(28 \%-\mathrm{S}$ and $39 \%-\mathrm{PK}$, respectively) was several times higher than that recorded in Norway spruce (Picea abies L.) $(10 \%)$; iii) tree species composition resulting from natural regeneration showed $95-100 \%$ proportion of Norway spruce despite the predominance of Scots pine in the maternal stand. These observations might provide evidence of unsuitable environmental conditions in the studied localities for pine forests on the southern range of the natural $P$. sylvestris occurrence. Forest management in similar ecological and climatic conditions should aim at significant diversification of the forest stand structure by utilizing tree species suitable for the given ecosystems.
\end{abstract}

\section{Keywords}

Bulgaria, health status, mycoflora, phytopathology, Pinus sylvestris L., regeneration capability

\section{Introduction}

In recent years, severe natural disturbances in forest ecosystems (mainly in spruce forests) have become more significant all over Europe (LAUSCH et al., 2011; MEZEI et al., 2011; NiKolov et al., 2014; KonôPKa et al., 2016). An important event in Bulgaria was the wind disturbance in the Western Rhodopes in 1961 when just in the locality of Selishte, 18,000 hectares of forest stands were strongly damaged and most trees uprooted (FEREZLIEV et al., 2017).
Several disturbances exceeding 300 ha affected mixed Picea abies-Pinus sylvestris forests in the Western Rhodopes also in the past (1984, 350 ha; 1983, >400 ha; 1997, $350 \mathrm{ha}$ ) as reported by PANAYotov et al. (2017). Except for the Beglika windthrow, no other large windthrows were recorded in the central and the highest parts of the Western Rhodopes.

A return to the original state (before a disturbance) takes several decades. The length of this reverse process depends on the time of regeneration of the subsequent

*Corresponding author: 
forest stands and on the speed of the regeneration of the soil-surface, while both processes are often influenced by the post-disturbance forest management (FISCHER et al., 2002).

The Scots pine (P. sylvestris L.) is a pioneer tree species regenerating spontaneously after major natural disturbances if weed competition and grazing pressures are low (Vitali et al., 2019). This tree has a wide ecological niche due to its ability to grow on dry and nutrient-poor soils. As such, it has frequently been used for reforestation. Scots pine is distributed over large areas of Europe, from northern Scandinavia to the Mediterranean region and from Spain to Turkey. It is an important commercial tree species within Europe; however, as a heliophilous tree it causes many problems with regeneration under the maternal stand. The lack of light can significantly limit the growth rate and quality of forest regeneration (BíLEK et al., 2018). In commercial forests, it is necessary to optimise the canopy cover of the maternal forest stand as a way facilitating the starting phase of regeneration (UlbRICHOví et al., 2018). Before seed germination, an important mortality factor in natural regeneration of $P$. sylvestris may be postdispersal predation of seeds by carabids (MARTINKoví et al., 2019). In the countries of western and southern Europe, the Scots pine, as well as other species of the genus Pinus, often form large forest complexes, mainly on exposed stands or on stands disturbed in other ways. BuEIs et al. (2016) found in northern Spain that the growth and productivity of pine forests is strongly limited by water availability and that high soil acidity causes the immobilisation of nutrients. On the other hand, the quality of soil microflora improves nutrient availability.

The increasing frequency of climatic changes and extremes in recent years, connected with extreme temperatures and increased precipitation deficit (MARTAZINOva et al., 2011; KouleLis et al., 2019), contributes to weakening of pine forest stands (RYU et al., 2018). This is often connected with outbreaks of bark-damaging pests and gradual collapse of forest stands. In 2016, insect pests in Slovakia attacked 68 thousand $\mathrm{m}^{3}$ of wood mass. Most abundant and most frequent species of bark beetle such as Ips acuminatus, I. sexdentatus or species Tomicus minor and T. piniperda (OLŠovsKÝ et al., 2013) were among the most significant pests. Pathogenic fungi (Cenangium ferruginosum, Ophiostoma spp.) also contributed to the dieback. Scots pine is also significantly weakened by mistletoe (Kunca et al., 2019). Similarly, PAstirčáKová et al. (2018) confirmed that drought (lack of precipitation) and increased temperatures in some regions of Slovakia during the growing season are support bark destroying insects and fungi in pine forests.

SCHÖNFELDER et al. (2017) evaluated the importance of site conditions, silvicultural measures and other factors for the density of Scots pine woods in the Czech Republic. The authors found that the highest wood density value was reached in a stand that had been regenerated using the shelter-wood method with long regeneration period, and the lowest wood density values were recorded in a stand regenerated using the clear-cutting method. Similarly, in mixed forests of the central part of the Rhodope Mountains in north-eastern Greece, P. sylvestris at the productive sites seems to exhibit faster height growth compared to that in Sweden; its growth is similar to that of the two most productive sites in the forests of north-western Spain and of fairly productive sites in north-western Turkey (MiLIos et al., 2018). The optimal management of pine forests was studied by Stankova (2017) who presented a dynamic distribution stand model for Scots pine plantations in Bulgaria. The whole-stand model component is developed by employing the state-space methodological approach. Due to its abilities as a pioneer tree, Scots pine is often used for reforestation of calamity-hit or otherwise disturbed areas as the main species or in a mix with other tree species that creates specific conditions for the growth, regeneration, vitality and management of such forest stands (SZMYT and TARASIUK, 2018).

The subjects of our study were 50-year-old stands of $P$. sylvestris, planted in disturbed areas after the year 1961 in the Western Rhodope Mountains in Bulgaria. We evaluated and compared the dendro-part of the forest ecosystems at the selected localities (Selishte and Pobit Kamak). To check the suitability of the use of Scots pine for reforestation of the investigated post-calamity areas, we evaluated the current state of the artificially renewed forest, with emphasis on three factors: the health of mature stands, analysis of phytopathogen-induced damage and the state of natural regeneration in the selected localities in the Western Rhodope Mountains.

\section{Materials and methods}

\section{Study sites}

The research object was a forest affected by the strong wind in the Western Rhodope Mountains in 1961. The investigations were carried out at two sites: i) Selishte (S), situated within in a pure white-grass culture developing on bare terrain after a wind disturbance, and ii) Pobit Kamak (PK) where remnants of Norway spruce were left and open areas were planted with Scots pine. At the Selishte site, in the early 1960 s, extensive forest areas were managed after a major wind disturbance. The area was reforested by planting Scots pine trees; now they are about 57 years old and subject to significant anthropogenic and phytopathogen-induced pressure. The surveyed stands (each $25 \times 150 \mathrm{~m}$ ) are located on one of the southern fringes of the natural occurrence of Scots pine in Europe (Fig. 1).

The main criteria for the selection of the studied sites were as follows: i) wind damage to forest stands; ii) planting activities carried out during subsequent afforestation in forest stands. The forest area characteristics are shown in Table 1.

\section{Natural forest regeneration}

Six plots were established in each forest stand, giving a total of 12 plots of dimensions $3 \mathrm{~m} \times 3 \mathrm{~m}\left(9 \mathrm{~m}^{2}\right)$. The plots were spaced randomly, at a distance of $25 \mathrm{~m}$ from each 


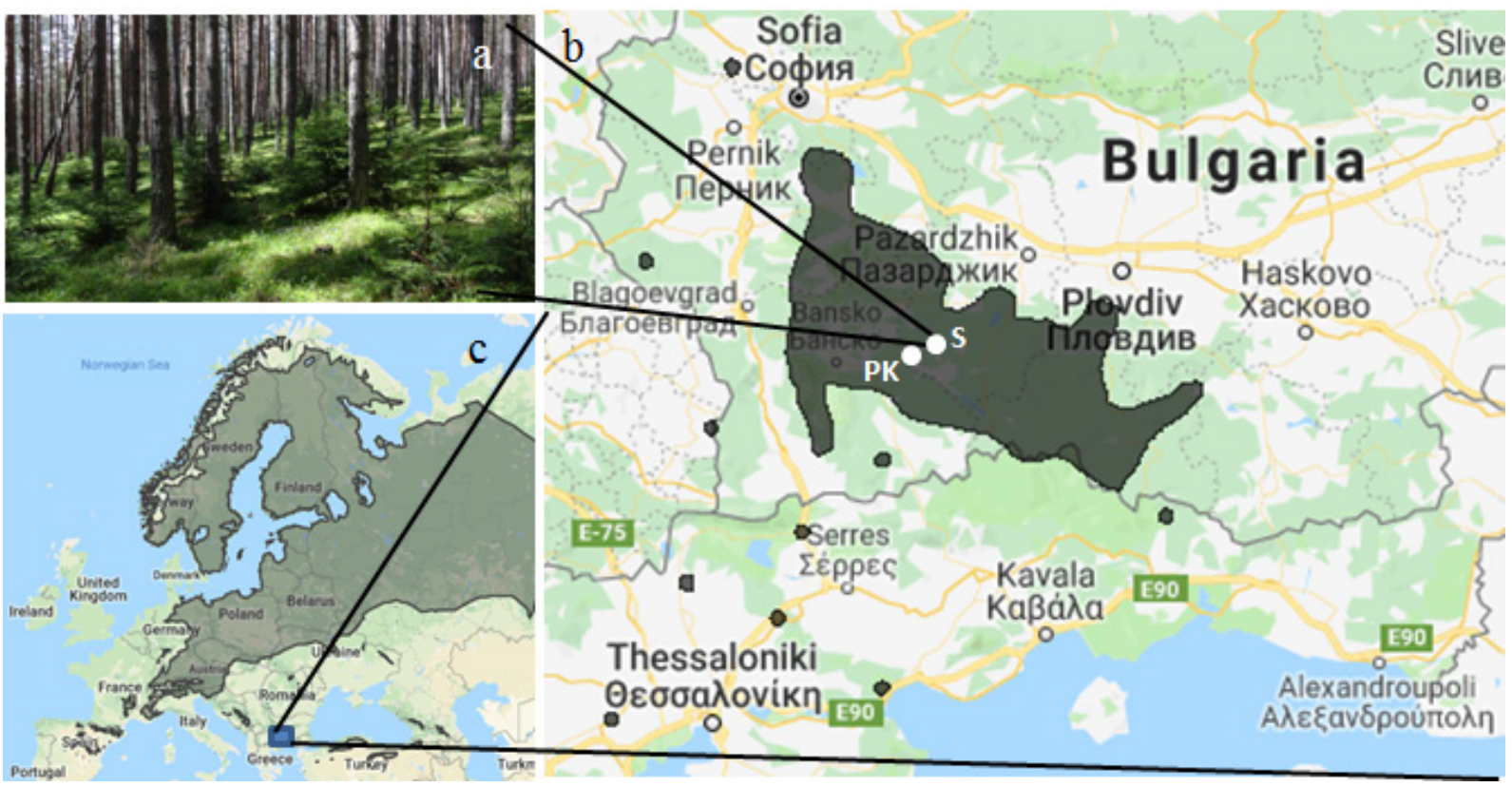

Fig. 1. a) Interior of the pine stand in Selishte with natural regeneration of Norway spruce. b) Distribution of Scots pine in Bulgaria and northern part of Greece (Rhodope Mountains) and location of the study sites (PK - Pobit Kamak, S - Selishte).

c) Natural distribution of the Scots pine within Europe (http://www.euforgen.org).

Table 1. Location and characteristics of the sites Pobit Kamak (PK) and Selishte (S)

\begin{tabular}{ccccccccccc}
\hline Site & $\begin{array}{c}\text { Altitude } \\
(\mathrm{m} \text { a.s.1.) }\end{array}$ & $\begin{array}{c}\text { Coordinates } \\
(\mathrm{N}, \mathrm{E})\end{array}$ & Soil type & Exposition & $\begin{array}{c}\text { Slope } \\
\text { Age }\end{array}$ & $\begin{array}{c}\text { Composition } \\
\left({ }^{\circ}\right)\end{array}$ & $\begin{array}{c}\text { Stems } \\
\text { density }\end{array}$ & $\begin{array}{c}\text { Mean } \\
\text { DBH* } \\
(\%)\end{array}$ & $\begin{array}{c}\text { Mean } \\
\text { height } \\
\left.(\mathrm{N} \mathrm{ha})^{-1}\right)\end{array}$ & $\begin{array}{c}\text { (cm) } \\
(\mathrm{m})\end{array}$ \\
\hline PK & 1,350 & $\begin{array}{c}41^{\circ} 49^{\prime} 54^{\prime \prime} \\
23^{\circ} 52^{\prime} 05^{\prime \prime}\end{array}$ & $\begin{array}{c}\text { Dystric-Eutric } \\
\text { Cambisols }\end{array}$ & $\begin{array}{c}\text { SW } \\
\text { down part }\end{array}$ & 6 & $\begin{array}{c}50 \\
70\end{array}$ & $\begin{array}{c}\text { P. sylvestris }(70) \\
\text { P. abies }(30)\end{array}$ & 759 & 23.3 & 21.6 \\
S & 1,475 & $\begin{array}{c}41^{\circ} 49^{\prime} 56^{\prime \prime} \\
23^{\circ} 54^{\prime} 46^{\prime \prime}\end{array}$ & $\begin{array}{c}\text { Dystric-Eutric } \\
\text { Cambisols }\end{array}$ & $\begin{array}{c}\text { SE } \\
\text { upper part }\end{array}$ & 16 & 50 & $\begin{array}{c}\text { P. sylvestris } \\
(100)\end{array}$ & 1,439 & 22.4 & 23.6 \\
\hline
\end{tabular}

*diameter at breast height.

other. Due to a high density of seedlings, each plot was divided into nine subplots. Therefore, the research was conducted on the $1 \mathrm{~m} \times 1 \mathrm{~m}$ subplots, and the variables recorded were: the number of seedlings from natural regeneration, the species composition and the seedling height (BARNA, 2015).

\section{Evaluation of phytopathogen-induced factors on ma- ture trees}

Only predominant and dominant mature trees were considered as sample trees for the purpose of crown and stem condition assessment (May 12, 2017). The spacing of the selected trees was sufficient so that the trees did not affect each other, at least to the average height of the stand (c.f. MıнÁL et al., 2019). At each plot, 16 sample trees were evaluated ( 8 predominant and 8 dominant trees).

We evaluated the presence of six factors of phytopathogen-induced damage to the crown and stem: i) resin outflow; ii) deformations of stems - necrotic wounds, bulges, neoplasm; iii) damage by game and animals peeling and biting the bark; iv) presence of fungi and rot fruiting bodies of lignicolous fungi, reddish brown rot; v) abiotic damage - discolouration by lightning, ice cracks, sunburned bark, breaks caused by snow and storms, vi) anthropogenic damage - mechanical damage to stem caused by man, e.g., logging, fire. We also estimated crown defoliation on the analysed trees. The defoliation was evaluated by ICP Forest methods (UN-ECE, 2008).

On the same samples, we also evaluated signs of attacks of bark-damaging insects. We evaluated the abundance of shoots (fallen from the crowns) that showed the signs of Tomicus minor Hartig feeding of the total number of shoots collected under trees within an area of $1 \mathrm{~m}$ diameter around the stem. The length $(\mathrm{cm})$ and thickness $(\mathrm{mm})$ of the shoots collected were measured.

During our field visits to Pobit Kamak in May 2016 and 2017, we carried out investigations of macromycetes (the presence of fruiting bodies and other determining 
signs) growing within the surveyed forest stand. No similar mycoflora investigation was performed in the Selishte locality, as this site is situated at high altitude, and the consequent climatic conditions are not favourable for fungal growth.

\section{Statistical analysis}

Comparisons of the variables related to natural regeneration and phytopathogen-induced damage between the investigated sites were carried out using the non-parametric Mann-Whitney $U$ test. We selected the Mann-Whitney $U$ test in preference to a parametric approach because investigation data was not normally distributed. The relationships between tree variables (height, age) were investigated using the Spearman non-parametric correlation. All analyses were performed in Statistica 9 (StatSoft Inc. 2009).

\section{Results}

\section{Natural forest regeneration}

The evaluation of the species composition of the natural regeneration at the sites $\mathrm{S}$ and $\mathrm{PK}$ resulted in finding that regenerated $P$. abies represented $95.4 \pm 4.6 \%$ (mean $\pm \mathrm{SE}$ ) and $100 \pm 0.0 \%$ of the tree species recorded, respectively (no significant difference between the sites was detected, $P=0.405)$, despite the dominance of $P$. sylvestris in the maternal stand (Table 1). The natural regeneration was significantly denser at the PK site (more than nine individuals per $\mathrm{m}^{2}$ ) than at site $\mathrm{S}$ (one individual $/ \mathrm{m}^{2}, P<0.001$ ). $\mathrm{PK}$ also displayed significantly greater variability in the number and age of the individuals resulting from natural recovery than did S (Table 2, Fig. 2).

Spearman's correlation confirmed a significant dependence between the age and height of individuals resulting from natural regeneration (Table 3); consequently, it can be assumed that there are good environmental conditions for the survival and growth of young trees (JARČUŠKA and BARNA, 2011a, b).

\section{Mature stand (defoliation, phytopathogen-induced damage, effects caused by fungi and Tomicus minor)}

A detailed assessment of phytopathogen-induced damage detected significant differences in only three of the assessed factors (Table 4): deformations, defoliation and T. minor. We also found the occurrence of resin outflow and anthropogenic damage, but differences between the sites were not confirmed. Observations for which no values were found are not included in Table 4 (i.e. damage by game and animals, presence of lignicolous fungi and abiotic damage). Incidence of damage by $T$. minor at $\mathrm{S}$ was two-fold higher than at PK. In total there were 74 records of feeding (fallen shoots from the crown damaged by $T$. minor) were made on 16 trees, i.e., an average of 4.6 records per tree (median 4.0). At the PK site, there were 34 records, i.e., 2.3 records per tree (median 1.0).

Table 2. Characteristics of the saplings arising from natural regeneration at site PK (Pobit Kamak) and S (Selishte) and the results of the Mann-Whitney $U$ test between the sites

\begin{tabular}{cccccc}
\hline Variable & Site & $n^{*}$ & Median & Z & $P$ \\
\hline No. per $\mathrm{m}^{2}$ & PK & 54 & 7.0 & 7.0740 & $<0.001$ \\
& $\mathrm{~S}$ & 54 & 1.0 & & $<0.001$ \\
Height $(\mathrm{cm})$ & PK & 511 & 8.0 & -8.7739 & $<0.001$ \\
Age $(\mathrm{yr})$ & $\mathrm{S}$ & 52 & 47.5 & & -8.4252 \\
\hline
\end{tabular}

*number of analyses.
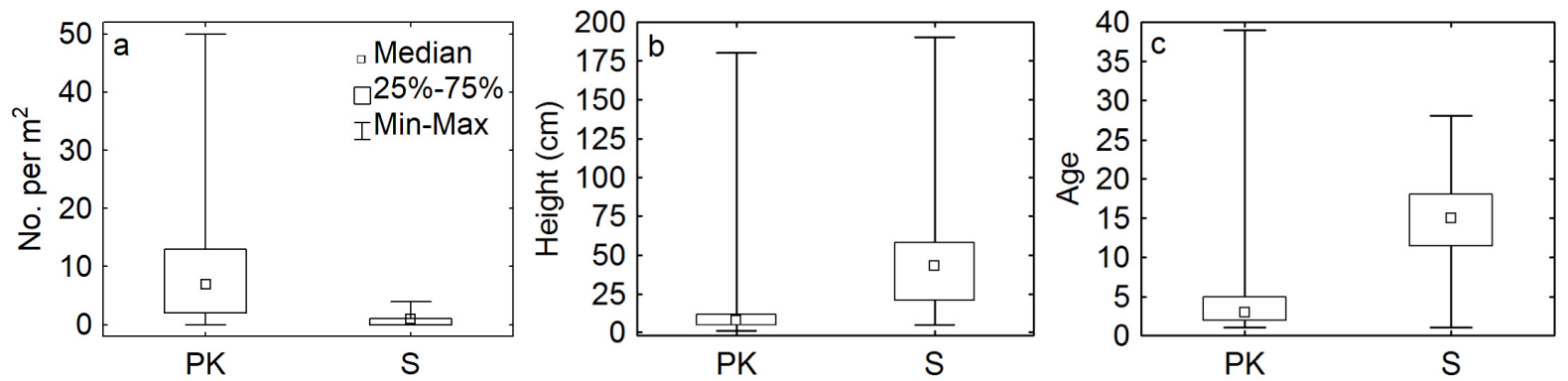

Fig. 2. The structure of natural regeneration: a) abundance, b) height and c) age at sites PK (Pobit Kamak) and S (Selishte). 
Table 3. Spearman's correlation between the height and age of saplings arising from natural regeneration (PK - Pobit Kamak, $\mathrm{S}-$ Selishte)

\begin{tabular}{ccccc}
\hline Site & $n^{*}$ & Spearman R & $\mathrm{t}(\mathrm{N}-2)$ & $P$ \\
\hline PK & 511 & 0.9134 & 50.6143 & $<0.001$ \\
S & 52 & 0.9017 & 14.7511 & $<0.001$ \\
\hline
\end{tabular}

*number of analyses.

Table 4. Comparison of phytopathogen-induced damage between the site Selishte (S) and Pobit Kamak (PK) using a MannWhitney $U$ test $\left(\mathrm{n}_{\mathrm{S}}=16, \mathrm{n}_{\mathrm{PK}}=16\right)$

\begin{tabular}{ccccc}
\hline Disease characteristics & $\mathrm{S}$ & $\mathrm{PK}$ & $\mathrm{Z}$ & \\
\hline & \multicolumn{2}{c}{ Median } & & \multirow{2}{*}{0.009} \\
Tomicus minor $\mathrm{L}$. & 4.0 & 1.0 & 2.610 & 0.005 \\
Defoliation & 25.0 & 40.0 & -2.817 & \\
& \multicolumn{2}{c}{ Proportion (\%) } & & 0.693 \\
Resin outflow & 25.0 & 18.8 & 0.395 & 0.038 \\
Deformations & 37.5 & 6.3 & 2.078 & 0.080 \\
Anthropogenic dam. & 18.8 & 0.0 & 1.753 & \\
\hline
\end{tabular}

In the surveys carried out in the pine and spruce forests of Pobit Kamak in May 2016 and 2017, we found altogether 17 species of macromycetes. Among interesting Ascomycota fungi, we can include, for example, Lachnellula occidentalis (G. G. Hahn \& Ayers) Dharne, Gyromitra esculenta (Pers.) Fr., Sarea resinae (Fr.) Kuntze and Vibrissea truncorum (Alb. \& Schwein.) Fr. These fungi are often found in submountain or mountain coniferous stands and are indicators of the original forest environment of spruce forests or of native forests with spruce representation. From the group of Basidiomycota fungi, we recorded old fruiting bodies and a rhizomorph of a harmful parasite Armillaria ostoyae (Romagn.) Herink as well as the species Stereum sanguinolentum (Alb. \& Schwein.) Fr. Among saprotrophic lignicolous species there were Dacrymyces stillatus Nees, Exidia saccharina Fr., Gloeocystidiellum ochraceum (Fr.) Donk and Tremella mesenterica Retz. The predominant species from this group of fungi was Strobilurus stephanocystis (Kühner \& Romagn. ex Hora) Singer, growing in bulk out of decomposing pine cones. The ectomycorrhizal symbionts Hebeloma sinapizans (Paulet) Gillet and Phellodon niger (Fr.) P. Karst. were also recorded.

\section{Discussion}

\section{Natural forest regeneration}

The natural regeneration showed considerable differences between the surveyed localities (in all the parameters studied, see Fig. 2, Table 2). Interestingly, we did not find a secured regeneration of pine in any plot, not even in the Selishte locality where the adult growth consists $100 \%$ of Scots pine. Of the 12 plots in which we analysed forest regeneration, there was only one plot where we detected pine (the density was less than one seedling per $2 \mathrm{~m}^{2}$ with an average height of $14.3 \mathrm{~cm}$, age 3-7 years and 22\% representation). Optimal regeneration establishment seems to be related to favourable conditions as regards annual and spring mean temperatures (VERGARECHEA et al., 2019). Precipitation levels of the summer and fall seasons of the previous and current year were found to have different effects on seedling and sapling ingrowth. A similarly important ecological factor in regeneration is canopy closure. Ulbrichoví et al. (2018) found that natural regeneration of pine under the surveyed stand (within a height range $0.25-4.00 \mathrm{~m}$ ) represented $4.3-18.5$ thousand $\mathrm{pcs} / \mathrm{ha}$. These numbers were significantly influenced by the maternal stand $(\mathrm{r}=-0.34)$. At a circular base above $25 \mathrm{~m}^{2} /$ ha, natural regeneration under the vegetation was minimal. The results of KARA and TOPAÇOĞLU (2018) confirm the previous findings, and they may partly explain the absence of pine in the post-calamity regeneration of the artificial stands in the localities surveyed in this work. In addition, the mean DBH for the successful regeneration of Scots pine is $23.7 \mathrm{~cm}$, which is close to the values measured at our sites $(\mathrm{PK}=22.4, \mathrm{~S}=23.3 \mathrm{~cm})$.

Despite its absence in the mature stand, spruce regenerated well. The explanation could be that the spruce seed is light, has a wing, and therefore is well dispersed by the wind and can fly several kilometres. Seed dispersal, after seed source and establishment, is the third most important factor limiting natural regeneration (CLARK et al., 1999; Paluch et al., 2019; White and Halpern, 2019; Gazda et al., 2019).

\section{Phytopathogen-induced damage of mature stand}

From the evaluated presence of seven factors of phytopathogen-induced damage to the crowns and stems of the sample trees, we found the occurrence of three factors 
only (Table 4). These values are similar to the data from the National Forest Inventory of the Slovak Republic. The least damaged tree species in Slovakia was also pine, for which up to $84 \%$ of undamaged stems were found. Rotting and mechanical damage did not exceed 10\% (ŠEBEŇ, 2017; Dobor et al., 2018). However, the loss of assimilation organs in S and PK (defoliation $28.2 \pm 2.23$ and 39.1 \pm $3.07 \%$ respectively) indicates a shift from slightly defoliated to medium defoliated stands. According to the Technical Report of ICP Forests (Michel and SEIDLing, 2017) on P. sylvestris, $77.8 \%$ of the Scots pine plots showed no or only slight defoliation ( $\leq 25 \%$ defoliation). Defoliation in $21.6 \%$ of the plots was moderate ( $>25-60 \%$ defoliation) and severe in $0.6 \%$ of the plots. Plots with the lowest mean defoliation (in 2016) were primarily found in southern Norway (13.5\%) and northern Germany (17.5\%), whereas plots with comparably high defoliation were located in the Czech Republic, Slovakia, southern France and Bulgaria. From 1992 to 2016, there was no overall trend in mean plot defoliation of Scots pine (regional Sen's slope $=0.0$, $P=0.321$ ). These long-term observations may indicate the correct choice of areas.

\section{Tomicus minor as an indicator of health status of ma- ture pine trees}

T. minor occurring on $P$. sylvestris is a species demonstrating a high reproductive capability in weakened stands, which accelerates the process of forest death. In protected areas, T. minor is regarded as a sensitive bioindicator, reflecting a decline in the health and vitality of forests. In addition, T. minor is a species that attacks weakened trees, accelerating the process of wood decomposition. This beetle may significantly impair the value of timber obtained from forests containing pine (BORKOWSKI and KOCHANOWSKI, 2017; OLŠOVSKÝ et al., 2013).

The intensity of attack by bark-damaging pests of the genus Tomicus in pine can also be assessed by different methods from the one we used. For example, RosNEv (2007) counted the number of beetle bore holes $/ \mathrm{dm}^{2}$ of pine bark (for example, for T. minor a number of bore holes below five meant a low degree of tree attack, above 10 meant a high degree of attack). TsANKov et al. (1997) observed the occurrence of the dangerous pests Ips acuminatus and Tomicus piniperda in the pines of Pobit Kamak in 1986. The authors concluded that $T$. piniperda also settled in habitats in the coniferous cultures created in the oak zone. Similarly, PAN et al. (2018) showed that T. minor is an active transmitter of the tracheomycotic species Ophiostoma tingens, inducing blue-stain in Pinus yunnanensis in China. TAKov et al. (2011) observed the occurrence of some pathogens of bark beetles (Coleoptera: Curculionidae) in Bulgarian forests. The authors reported the occurrence of T. piniperda (118 adults) and T. minor (13 exemplars) on Scots pine trees in the Rhodopi above Velingrad, which is close to our sites. The authors stated that a total of $27.9 \%$ of $T$. piniperda adults and $15.4 \%$ of $T$. minor adults were infected with nematodes.

\section{Mycoflora}

In the Pobit Kamak stand, we found 17 species of macromycetes. Considering the climatic conditions at the begin- ning of May, the species diversity mentioned above seems lower than expected; however, there is a high probability of the occurrence of a number of saprotrophic and particularly symbiotic macromycetes in these stands during the climatic favourable months of June, July and, particularly, September and October. From a phytopathological point of view, among significant species we could include $\mathrm{Ar}$ millaria ostoyae and Stereum sanguinolentum which, in favourable conditions, can spread significantly and cause serious damage in the stands. For example: A. ostoyae, as a spruce and pine parasite, spreads through rhizomorphs via damaged roots, and $S$. sanguinolentum, a so called 'wound parasite', infects bark damage arising from animal bites or other mechanical bark damage (MIHÁL, 1996; ČERMÁK and STREJČEK, 2007). The results of the transnational monitoring network of ICP Forests in 2016 show that fungi, as damaging agents, were most important in Austrian pine trees $(21.3 \%)$, deciduous temperate oaks $(15.6 \%)$ and Scots pine trees (15.8\%) (Michel and SEIDLING, 2017).

Parasitic fungi, as an important factor in pine forest dieback, are also mentioned by RosNev et al. (2008) who have analysed the changes in the health condition of the Scots pine plantations in Southwestern Bulgaria in the 1986-2005 period. Important factors affecting the health of the plants are the diseases caused by Heterobasidion annosum and Armillaria mellea. They were found in 39.1\% of the sample plots. The pathogen species $C$. ferruginosum was also recorded.

Of the fungi considered as pests on Scots pine in Bulgaria (DoBreva et al., 2016) the following species can be mentioned: Botrytis cinerea, Alternaria alternata, Lophodermium pinastri, Lophodermium seditiosum, Cyclaneusma minus, C. niveum, Sclerophoma pithyophila, Dothistroma pini, Sphaeropsis sapinea and C. ferruginosum, as well as the fungus $C$. acuum - a new species of mycoflora in Bulgaria. Among the infrequent records of fungi at Pobit Kamak there was the record of the fungus Auriscalpium vulgare Gray - an endangered species in the Red Book of Fungi of Bulgaria (Goysheva et al., 2006; LACHEVA, 2014), as well as the records of Lachnellula occidentalis, Sarea resinae, Vibrissea truncorum and Gloeocystidiellum ochraceum, the occurrence of which was not previously known in Bulgaria.

\section{Notes on the management of Scots pine forest stands}

One way to improve the health and stability of pine stands is by growing mixed pine stands. For example, in the pine forest stand with a $20-30 \%$ share of oak (Quercus petraea), there was an increase in pine increments (ŠPULÁK al., 2018). The increase in DBH in a mixed stand with almost a half share of spruce and pine mixture was also confirmed, reaching an increase of 33\%. Similarly, SzMYT and DobrowolsKa (2016) emphasised the role of evenaged, one-layered monocultures of pine stands before the former blown-down forest can be replaced by more diversified forests reflecting a more complex structure in terms of the spatial distribution, species composition and size differentiation. Despite the presence of pioneer trees (pine and birch), late-succession tree species (e.g., beech) 
can be found in the regeneration, and the different damage levels play a role in modifying the species composition and abundance. Even in the Tatras Mountains in Slovakia, artificial regeneration has helped to increase species diversity, which was obvious mainly at lower altitudes. A certain share of larch and pine in new stands can increase the stability of forest stands in the future (NIKOLOV et al., 2014; KonôpKa et al., 2018). Pine, as one of the most light-demanding species, is likely to be negatively affected by a progressively closing canopy. The negative impact of the changes in forest management of this species is evident from the very low cover of pine regeneration compared to the vigorous regrowth of beech, fir and spruce (Bosela et al., 2019). The authors found that the pine forest stands with beech, fir and spruce, where the proportion of pine was $61 \pm 17 \%$, exhibited an extremely low occurrence of pine in natural regeneration (only $2 \%$ of 344 sample plots, with an average cover of up to $2 \%$ ).

The unsuitability of the pine monocultures produced during the reforestation 57 years ago in the Western Rhodope Mountains in Bulgaria is highlighted by the attributes we have identified, in particular: i) the occurrence of a bark-damaging pest $T$. minor; ii) a significant loss of assimilation organs in the surveyed stands (moderate defoliation), whereas the defoliation of spruce at Pobit Kamak (10.3\%) was significantly lower than that of pine (39.1\%); (iii) an unequivocal manifestation of an inappropriate environment for pine trees at Pobit Kamak and Selishte is the absence of natural pine regeneration. Our findings indicate a need for a significant diversification of the composition of the main stand in the surveyed localities. In consequent forest management it would be advisable to bring the spruce back to the stand level. There should be no problem, as the conditions for germination and the survival of the natural regeneration of spruce are satisfactory (BRANG, 1998; DiACI et al., 2020).

\section{Acknowledgements}

This work was accomplished with a financial support from and in accordance with the scientific objectives of the VEGA projects no. 2/0101/18 and the Inter-Academic Agreement (SK-BG) project entitled: "Evaluation of natural regeneration and succession processes in forests with disrupted structure in the Rhodope Mts (Bulgaria) and Tatra Mts (Slovakia)". The authors express thanks to their former colleague Dr. Alojz Cicák, for an active approach to the field research.

\section{References}

BARna, M., 2015. Productivity and functioning of the beech ecosystem: Ecological Experimental Station - Kremnické vrchy Mts. (Western Carpathians). Lesnicky Časopis Forestry Journal, 61: 252-261.

Bílek, L., VaceK, Z., VaceK, S., BulušeK, D., Linda, R., KRÁL, J., 2018. Are clearcut borders an effective tool for
Scots pine (Pinus sylvestris L.) natural regeneration? Forest Systems, 27: article number e010, $14 \mathrm{p}$.

Borkowski, A., Kochanowski, J., 2017. The colonisation of Scots pine (Pinus sylvestris L.) by Tomicus minor Hartig in southern Poland: modelling and monitoring. European Journal of Forest Research, 136: 893-906.

Bosela, M., Kulla, L., Roessiger, J., ŠebeŇ, V., Dobor, L., BüNTGEN, U., LuKAC, M., 2019. Long-term effects of environmental change and species diversity on tree radial growth in a mixed European forest. Forest Ecology and Management, 446: 293-303.

Brang, P. 1998. Early seedling establishment of Picea abies in small forest gaps in the Swiss Alps. Canadian Journal of Forest Research, 28: 626-639.

Bueis, T., Bravo, F., Pando, V., Turrion, M-B., 2016. Relationship between environmental parameters and Pinus sylvestris L. site index in forest plantations in northern Spain acidic plateau. iForest, 9: 394-401.

Clark, J.S., Silman, M., Kern, R., Macklin, E., HillerisLAMBERS, J., 1999. Seed dispersal near and far: patterns across temperate and tropical forests. Ecology, 80: 14751494.

Čermák, P., StrejČEK, M., 2007. Stem decay by Stereum sanguinolentum after red deer damage in the Českomoravská vrchovina highlands. Journal of Forest Science, 53: 567572.

Diaci, J., Rozman, J., Rozman, A. 2020. Regeneration gap and microsite niche partitioning in a high alpine forest: are Norway spruce seedlings more drought-tolerant than beech seedlings? Forest Ecology and Management, 455: article number 117688. https://doi.org/10.1016/j.foreco.2019.117688

Dobor, L., Hlásny, T., Rammer, W., Barka, I., Trombik, J., Pavlenda, P., ŠEbeň, V., ŠtěPÁneK, P., Seidl, R., 2018. Post-disturbance recovery of forest carbon in a temperate forest landscape under climate change. Agricultural and Forest Meteorology, 263: 308-322.

Dobreva, M., Georgieva, M., Dermedzhiev, P., Nachev, R., Velinov, V., Terziev, P., Georgiev, G., 2016. Fungal pathogens associated with Pinus species in the region of Forest Protection Station Plovdiv in the period 20132016. Nauka za Gorata - Forest Science, 1-2: 103-116.

Ferezliev, A., Tsakov, H., Minál, I., CicÁk, A., 2017. Osobenosti $\mathbf{v}$ stroježa po diametr na drvnostoji, rastrojeni ot uraganen viatr $\mathbf{v}$ zapadni Rodopi [Pecularities in diameter structure in stands updet by hurricane in the west Rhodopes]. Nauka za Gorata - Forest Science, 1: 53-63.

Fischer, A., Lindner, M., Abs, C., Lasch, P., 2002. Vegetation dynamics in central European forest ecosystems (near nature as well as managed) after storm events. Folia Geobotanica, 37: 14-32.

Gazda, A., Kościelniak, P., Hardy, M., Muter, E., Kędra, K., Bodziarczyk, J., Frączek, M., Chwistek, K., RÓŻAŃSKI, W., SZWAGRZYK, J., 2019. Upward expansion of distribution ranges of tree species: contrasting results from two national parks in Western Carpathians. Science of the Total Environment, 653: 920-929.

Goysheva, M.M., Denchev, C.M. Dimitrova, E.G., Assyov, B., Petrova, R.D., Stoichev, G.T., 2006. Red List of fungi in Bulgaria. Mycologia Balcanica, 3: 81-87.

JARČUŠKA, B., BARNA, M., 2011a. Influence of light availability on height growth of naturally regenerated beech with 
different growth histories. Austrian Journal of Forest Science, 128: 53-65.

JARČUŠKA, B., BARNA, M., 2011b. Plasticity in above-ground biomass allocation in Fagus sylvatica L. saplings in response to light availability. Annals of Forest Research, 54: $151-160$.

Kara, F., TopaçoĞLu, O., 2018. Onset of canopy closure for black pine, Turkish red pine and Scots pine forests. Journal of Forest Science, 64: 224-229.

KonôPKa, B., Zach, P., Kulfan, J., 2016. Wind - an important ecological factor and destructive agent in forests. Lesnícky časopis - Forestry Journal, 62: 123-130.

KonôPKa, B., Pajtík, J., Shipley, LA., 2018. Intensity of red deer browsing on young rowans differs between freshlyfelled and standing individuals. Forest Ecology and Management, 429: 511-519.

Koulelis, P.K., Daskalakou, E.N., IoAnnidis, K.E., 2019. Impact of regional climatic conditions on tree growth on mainland Greece. Folia Oecologica, 46: 127-136.

KunCa, A., ZúBrik, M., Galko, J., VaKula, J., Leontovyč, R., KonôpKa, B., Nikolov, Ch., GubKa, A., Longauerová, V., Malová, M., Rell, S., Lalík, M., 2019. Salvage felling in the Slovak Republic's forests during the last twenty years (1998-2017). Central European Forestry Journal, 65: 3-11. https://doi.org/10.2478/forj-20190007

LACHEva, M., 2014. A study of larger fungi of the Boraka Managed Reserve, Central Rhodopes Mts. Ecologia Balkanica, 5: 115-121.

LausCh, A., Fahse, L., Heurich, M., 2011. Factors affecting the spatio-temporal dispersion of Ips typographus (L.) in Bavarian Forest National Park: a long-term quantitative landscape-level analysis. Forest Ecology and Management, 261: 233-245.

Martazinova, V., Ivanova, O., Shandra, O., 2011. Climate and treeline dynamics in the Ukrainian Carpathians Mts. Folia Oecologica, 38: 66-72.

Martinková, Z., Koprdová, S., Kulfan, J., Zach, P., HonĚK, A., 2019. Ground beetles (Coleoptera: Carabidae) as predators of conifer seeds. Folia Oecologica, 46: 37-44.

Mezei, P., JAKuš, R., BlažEnec, M., BeláNOvá, S., ŠMíDT, J., 2011. Population dynamics of spruce bark beetle in a nature reserve in relation to stand edges conditions. Folia Oecologica, 38: 73-79.

Michel, A., Seidling, W. (eds), 2017. Forest condition in Europe: 2017 technical report of ICP Forests. Report under the UNECE Convention on Long-Range Transboundary Air Pollution (CLRTAP). BFW Dokumentation, 24/2017. Vienna: BFW Austrian Research Centre for Forests. $128 \mathrm{p}$.

MıнÁL, I., 1996. Vplyv t’ažbového zásahu rôznej sily na produkciu biomasy plodníc podpňovky smrekovej - Armillaria ostoyae (Romagn.) Herink [Influence of different cutting operation on fruiting bodies biomass production of the honey gungus - Armillaria ostoyae (Romagn.) Herink]. Lesnicky Časopis - Forestry Journal, 42: 241-248.

Mihál, I., Marušák, R., Barna, M., 2019. Dynamics of Fagus sylvatica L. necrotization under different pollutant load conditions. Polish Journal of Environmental Studies, 28: 2755-2763.

Milios, E., Kitikidou, K., Pipinis, E., Stampoulidis, A., Akritidou, S., Smiris, P., 2018. Site quality assessment for Pinus sylvestris L. in mixed forests of the central part of "Rhodope Mountains" in northeastern Greece. Annals of Silvicultural Research, 42: 79-84.

Nikolov, C., Konôpka, B., KajBa, M., Galko, J., Kunca, A., JANSKÝ, L., 2014. Post-disaster forest management and bark beetle outbreak in Tatra National Park, Slovakia. Mountain Research and Development, 34: 326-335.

OlŠOvskÝ, T., ZACH, P., Kulfan, J., JuRÍKOvÁ-Matulová, Z., 2013. Spatial occurrence and abundance of five phloeophagous beetle species (Coleoptera) in Scots pine trees (Pinus sylvestris) growing on sandy soils. Folia Oecologica, 40: 84-90.

Paluch, J., Bartkowicz, L., Moser, W.K., 2019. Interspecific effects between overstorey and regeneration in small-scale mixtures of three late-successional species in the Western Carpathians (southern Poland). European Journal of Forest Research, 138: 889-905.

Pan, Y., Chen, P., Lu, J., Zhou, X.D., Ye, H., 2018. First report of blue-stain in Pinus yunnanensis caused by Ophiostoma tingens associated with Tomicus minor in China. Abstracts of presentations at the XXIV Congress of the Italian Phytopathological Society, September 5-7, 2018, Marche Polytechnical University, Ancona, Italy. Journal of Plant Pathology, 100: 613-653.

Panayotov, M., Gogushev, G., Tsavkov, E., Vasileva, P., Tsvetanov, N., Kulakowski, D., BeBI, P., 2017. Abiotic disturbances in Bulgarian mountain coniferous forests an overview. Forest Ecology and Management, 388: 1328. https://doi.org/10.1016/j.foreco.2016.10.034

Pastirčáková, K., Adamčíková, K., PastirčÁK, M., Zach, P., Galko, J., Kováč, M., Laco, J., 2018. Two bluestain fungi colonizing Scots pine (Pinus sylvestris) trees infested by bark beetles in Slovakia, Central Europe. Biologia, 73: 1053-1066.

Rosnev, B. (ed.), 2007. Rukovodstvo po zashtita na gorite [Forest Protection Guide II. Part]. Sofia: Ministry of Agriculture and Forestry, National Forest Administration, Forest Research Institute, Bulgarian Academy of Sciences. $128 \mathrm{p}$.

Rosnev, B., Mirchev, P., Petkov, P., Georgiev, G., Tsankov, G., Matova, M., Georgieva, M., 2008. Izmenenja v zdravoslovnoto sostojanie na kulturi ot bjial bor (Pinus sylvestris L.) v rajona na jugozapadna Bulgaria prez perioda 1986-2005 [Changes in the health condition of the Scots pine (Pinus sylvestris L.) plantations in Southwestern Bulgaria during the period 1986-2005]. Plant Science, 45: 393-397.

Ryu, M., Mishra, R.C., Jeon, J., Lee, S.K., Bae, H., 2018. Drought-induced susceptibility for Cenangium ferruginosum leads to progression of Cenangium-dieback disease in Pinus koraiensis. Scientific Reports, 8: article number 16368.

Schönfelder, O., Zeidler, A., BorŮVKA, V., Bilek, L., 2017. Influence of site conditions and silvicultural practice on the wood density of Scots pine (Pinus sylvestris L.) - a case study from the Doksy locality, Czech Republic. Journal of Forest Science, 63: 457-462.

Stankova, T., 2017. Savrmenen dinamitchen model za pastezh, stroezh i proizvoditelnost na bjialborovite kulturi $v$ nas [Contemporary dynamic model for growth, yield and structure of Scots pine plantations in Bulgaria]. Nauka za Gorata - Forest Science, 1: 3-15. 
SzmYt, J., DobrowolSKa, D., 2016. Spatial diversity of forest regeneration after catastrophic wind in northeastern Poland. iForest, 9: 414-421.

Szmyt, J., Tarasiuk, S., 2018. Species-specific spatial structure, species coexistence and mortality pattern in natural, uneven-aged Scots pine (Pinus sylvestris L.)-dominated forest. European Journal of Forest Research, 137: 1-16.

ŠEBEŇ, V., 2017. Národná inventarizácia a monitoring lesov Slovenskej republiky 2015-2016 [National forest inventory and monitoring of the Slovak Republic 2015-2016]. Lesnícke štúdie, 65. Zvolen: Národné lesnícke centrum. $255 \mathrm{p}$.

ŠPulÁK, O., SOUČEK, J., ČERnÝ, J., 2018. Do stand structure and admixture of tree species affect Scots pine aboveground biomass production and stability on its natural site? Journal of Forest Science, 64: 486-495.

Takov, D., Doychev, D., Linde, A., Draganova, S., PilaRSKA, D., 2011. Pathogens of bark beetles (Coleoptera: Curculionidae) in Bulgarian forests. Phytoparasitica, 39: 343-352.

Tsankov, G., Mirchev, P., Tomovsky, H., 1997. Proutchvanije na drvesinoiadite i koroiadite $\mathrm{v}$ bjialborovi ekosistemi $\mathrm{v}$ Bulgaria [A study on wood eaters and bark beetles in
Scots pine ecosystems in Bulgaria]. Nauka za GorataForest Science, 3-4: 71-83.

Ulbrichová, I., JaneČEK, V., VítÁMVÁs, J., ČERnÝ, T., BíleK, L., 2018. Clonná obnova borovice lesní (Pinus sylvestris L.) ve vztahu ke stanovištním a porostním podmínkám [Curtain restoration of Scots pine (Pinus sylvestris L.) in relation to habitat and stand conditions]. Zprávy Lesnického Výzkumu, 63: 153-164.

Un-Ece, 2008. Forest condition in Europe 2008 - technical report of ICP Forest. Hamburg: Johann Heinrich von Thünen-Institut. $107 \mathrm{p}$.

Vergarechea, M., del Río, M., Gordo, J., Martín, R., CuBero, D., Calama, R., 2019. Spatio-temporal variation of natural regeneration in Pinus pinea and Pinus pinaster Mediterranean forests in Spain. European Journal of Forest Research, 138: 313-326.

Vitali, A., Garbarino, M., Camarero, J.J., Malandra, F., Toromani, E., Spalevic, V., Čurović, M., Urbinati, C., 2019. Pine recolonization dynamics in Mediterranean human-disturbed treeline ecotones. Forest Ecology and Management, 435: 28-37.

Received October 22, 2019 Accepted December 3, 2019 